\title{
Carbon Credit Estimation: A Case Study of Shifting Freighting Mode to Railway from ICD Lat Krabang, Bangkok to Laem Chabang Port, Chonburi
}

\author{
Nantarat Tangvitoontham and Papusson Chaiwat
}

\begin{abstract}
This study aims to investigate the estimation of greenhouse gas emissions and simply analyzing the value of carbon credits of the government's project, Rail Transfer Terminal Center at Inland Container Depot (ICD) Lat Krabang, Bangkok and Laem Chabang Port, Chonburi. The results reveal that the reduction of greenhouse gases (GHG) is at high rate and increases every year. As you can see, the emission of carbon dioxide equivalent reduces averagely 201,256.60 tCO2e per year. Additionally, government can gain from carbon credit approximately 90.84 million baht per year.
\end{abstract}

Index Terms-Carbon credit estimation, carbon dioxide emission estimation, environmental valuation, environmental economics.

\section{INTRODUCTION}

Nowadays, the world is facing a climate change. Economic activities are the major cause of greenhouse gases (GHG) emission to the atmosphere, which leads to a global warming. From these reasons, many countries have reached an agreement on climate change and trading greenhouse gases, which is called "carbon credit". Both government and the private sector can trade through the Clean Development Mechanism (CDM) under the Kyoto Protocol. Carbon credit is the amount of greenhouse gases that reduce from human and economic activities. There are several types of gases such as carbon dioxide, methane, nitrous oxide hydro fluorocarbon, perfluocarbons and sulphur hexafluoride [1]. Carbon credits are an important tool in reducing greenhouse gas emissions through the mechanism as well as an new source of government revenue [2]. Thailand is also a member and obligates to perform under the clean development mechanism as well. Additionally, Thailand may be forced to reduce the amount of greenhouse gases in the next 10 years as well. Therefore, it should reduce the usage of energy consumption simultaneously. The government should also encourage reducing emissions by investing in the infrastructure of the country to contribute to environmental preservation and create a sustainable development.

\section{CASE STUdy BACKGROUND}

Thailand's government creates a master plan for reducing

Manuscript received September 7, 2013; revised November 10, 2013.

N. Tangvitoontham is with the School of Economics and Public Policy, Srinakharinwirot University (e-mail: ntploy@yahoo.com).

P. Chaiwat is with the Faculty of Graduate School of Management and Innovation, King Mongkut's University of Technology Thonburi.
GHGs emission since 2012. Regarding to the statistics from National Statistical Office, we found that the highest energy consumption is in industry sector which accounts for 35.9 percent following by transportation sector which accounts for 35.4 percent of all energy consumptions [3]. As you can see the transportation sector consumes approximately one third of the country's energy consumption and tends to increase year by year. Regarding to the Kyoto Protocol and Thailand's government obligation to reduce GHGs emission, the Office of Transportation and Traffic Policy and Planning (OTP) announces the development master plan for a sustainable transportation and logistics system.

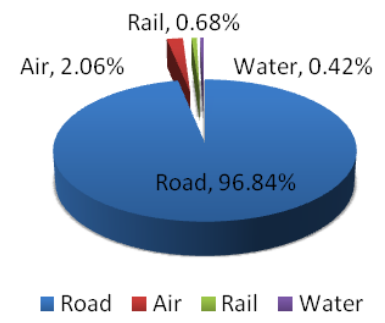

Source: Thailand greenhouse gas management organization

Fig. 1. $\mathrm{CO}_{2}$ emissions from the transportation sector in Thailand

Fig. 1 shows that $\mathrm{CO}_{2}$ emission from road transportation is 96.84 percent followed by the emission from air transportation (2.06 percent), railway transportation (0.68 percent) and water transportation $(0.42 \%)$ [4]. Since the energy consumption in the road transportation sector is very high, it is necessary to create the project in order to support changing transportation mode for reducing air pollution and greenhouse gas emissions. OTP plans to invest in green transportation system and encourage business sector to use transportation mode which have lower emission rates instead. One of the main projects of the government which defined in the master plan is "Rail Transfer Terminal Center" at Inland Container Depot (ICD) Lat Krabang, Bangkok and Laem Chabang Port, Chonburi. This project objects to reduce the truck freighting and encourage railway freighting from ICD Lat Krabang to Laem Chabang Port. Therefore, this study aims to investigate the estimation of greenhouse gas emissions and simply analyzing the value of carbon credits in this government's project.

\section{Methodology}

The benefits from $\mathrm{CO}_{2}$ emission reduction will occur only if the project is established. Therefore, the benefit from 
changing mode of transportation will be determined around where the organization is located. The carbon credit reflects the net benefit of the project. Thus, the results are the different of $\mathrm{CO}_{2}$ emission from train and truck between with and without the project.

Also, the study assumes that the lifetime of the project is 30 years, so the estimation will be start from year 2014 to year 2043. According to the project feasibility report of OTP, the demand for freighting from ICD Lat Krabang to Laem Chabang Port was already estimated by using econometric model. The econometric models for freighting demand are as follows [5]:

$$
\begin{aligned}
\mathrm{LCP}=- & 3726727+1.9528 \mathrm{RGDP} \\
& \left(R^{2}=0.9674\right) \\
\mathrm{LICD}= & 121406.2+0.3097 \mathrm{LCP} \\
& \left(R^{2}=0.9817\right)
\end{aligned}
$$

where

LCP $=$ Containers in Laem Chabang Port (TEU)

RGDP $=$ Real Gross Domestic Product (Million Baht)

LICD = Containers which deliver from ICD Lat Krabang to Laem Chabang Port (TEU)

There are two scenarios in this study as follows:

\section{A. Without the Project}

Since there is no project, the proportion of freighting by truck and railway remain unchanged. The proportion is 74:26 Therefore, the container deliveries by railway are limited at 500,000 TEU per year and will be increased to 1,000,000 TEU in 2015 because there is a plan to increase the trips from 10 to 20 trips per day.

\section{B. With the Project}

If the project is established, the potential of railway freighting will be raised. The freighting by railway is faster and more convenience. The proportion of freighting by truck and railway will be changed to 60:40. Therefore, the capacity of container deliveries by railway is 2,000,000 TEU per year.

Moreover, in order to calculate carbon credit of the project, there are several variables to explore such as Conventional Factor [6] and Emission Factors [7]. OTP's study in 2011 revealed that the different vehicles at various speeds consume fuels such as gasoline, diesel, gas, LPG and NGV differently. It can create different multiplier emissions which are called "Emission Factors (EF)" These EFs are used to estimate the air pollution emission in transportation sector which are shown in Table I.

TABLE I: POLLUTION EMISSION IN TRANSPORTATION SECTOR
\begin{tabular}{|l|c|c|}
\hline $\begin{array}{c}\text { Pollution Emission in } \\
\text { Transportation Sector }\end{array}$ & $\begin{array}{c}\text { Nation level } \\
\text { (million tons) }\end{array}$ & $\begin{array}{c}\text { Bangkok } \\
\text { (million tons) }\end{array}$ \\
\hline Hydrocarbon $(\mathrm{HC})$ & 0.04 & 0.03 \\
\hline Carbon monoxide $(\mathrm{CO})$ & 0.62 & 0.15 \\
\hline Nitrogen oxides $\left(\mathrm{NO}_{\mathrm{x}}\right)$ & 0.24 & 0.11 \\
\hline carbon dioxide $\left(\mathrm{CO}_{2}\right)$ & 39.21 & 18.21 \\
\hline
\end{tabular}

Source: Office of transportation and traffic policy and planning

Additionally, IPCC Second Assessment (1995) reported that different types of pollutants have potential to warm the climate differently. Consequently, its research determines the potential of various gases to heat the globe which is called "Global Warming Potential (GWP)" which shows in Table II. This study is considered three types of greenhouse gases which are carbon dioxide $\left(\mathrm{CO}_{2}\right)$, nitrous oxide $\left(\mathrm{N}_{2} \mathrm{O}\right)$ and methane $\left(\mathrm{CH}_{4}\right)$ [8].

TABLE II: GHGS CONTROLLED UNDER THE KYOTO PROTOCOL AND GLOBAL WARMING POTENTIAL

\begin{tabular}{|l|c|}
\hline \multicolumn{1}{|c|}{ AND GLOBAL WARMING POTENTIAL } \\
\hline 1. Carbon dioxide $\left(\mathrm{CO}_{2}\right)$ & GWP \\
(Carbon Dioxide Equivalent: \\
\hline 2. Methane $\left(\mathrm{CH}_{4}\right)$ & 1 \\
\hline 3. Nitrous oxide (N2O) & 21 \\
\hline $\begin{array}{l}\text { 4. Hydrofluorocarbon } \\
\text { (HFCs) }\end{array}$ & $140-11,700$ \\
\hline $\begin{array}{c}\text { 5. Perfluocarbons (PFCs) } \\
\text { 6. Sulphur hexafluoride } \\
\text { (SF6) }\end{array}$ & $6,500-9,200$ \\
\hline Source: Climate change 1995, IPCC second assessment report
\end{tabular}

However, emissions from each type of vehicle are not equal, so this study will use the Emission Factor (EF) to explain and clarify the estimation of GHGs emission from different type of vehicles as well. Table III shows the EF index of land transportation including truck and train [9].

TABLE III: INDEX OF VEHICLE's GHGS EMISSION (LAND TRANSPORTATION)

\begin{tabular}{|l|c|c|c|}
\hline \multicolumn{1}{|c|}{ Type of Vehicles } & $\mathrm{CO}_{2}(\mathrm{~g} / \mathrm{km})$ & $\begin{array}{c}\mathrm{N}_{2} \mathrm{O} \\
(\mathrm{g} / \mathrm{km})\end{array}$ & $\begin{array}{c}\mathrm{CH}_{4} \\
(\mathrm{~g} / \mathrm{km})\end{array}$ \\
\hline $\begin{array}{l}\text { Light Duty Petrol }(<3.5 \\
\text { tonnes) }\end{array}$ & 297.5 & 0.0055 & 0.075 \\
\hline $\begin{array}{l}\text { Light Duty Diesel (<3.5 } \\
\text { tonnes) }\end{array}$ & 280 & 0.0200 & 0.005 \\
\hline $\begin{array}{l}\text { Light Duty LPG/CNG (<3.5 } \\
\text { tonnes) }\end{array}$ & 180 & 0.0050 & 0.180 \\
\hline $\begin{array}{l}\text { Heavy Duty Petrol (>3.5 } \\
\text { tonnes) }\end{array}$ & 535 & 0.0060 & 0.100 \\
\hline $\begin{array}{l}\text { Heavy Duty Diesel (>3.5 } \\
\text { tonnes) }\end{array}$ & 3,188 & 0.08 & 0.215 \\
\hline $\begin{array}{l}\text { Heavy Duty LPG/CNG } \\
\text { (>3.5 tonnes) }\end{array}$ & 550 & N/A & N/A \\
\hline $\begin{array}{l}\text { Motorcycles Petrol } \\
\text { Diesel electric emissions }\end{array}$ & 0.0300 & 0.060 \\
\hline
\end{tabular}

Souce: New Zealand transport agency research report 497

In this study, trucks transportation bases on Heavy Duty Diesel (> 3.5 Tons) in EF index. Railway transportation will be assumed the weight of fuel 1 liter equals to $0.8 \mathrm{~kg}$, and the 
oil is approximately 4 liters per kilometer. Both transportation modes is calculated by using the same distance which is from the ICD Lat Krabang, Bangkok to Laem Chabang Port, Chonburi (115 kilometers).

Also, the OTP's research found that the emissions of the pollutants tend to decrease if the average speed of the vehicle is increasing. For example, the Heavy Duty Diesel emits $\mathrm{CO}_{2}$ $821 \mathrm{~g} . / \mathrm{km}$. at the speed of $30 \mathrm{~km}$./ hour while the emission rate decreases to $577 \mathrm{~g} . / \mathrm{km}$. at the speed of $60 \mathrm{~km}$./ hour. The Light Duty Diesel emits $\mathrm{CO}_{2} 203 \mathrm{~g} . / \mathrm{km}$. at the speed of 30 $\mathrm{km}$./ hour while the emission rate decreases to $154 \mathrm{~g} . / \mathrm{km}$. at the speed of $60 \mathrm{~km} . /$ hour.

The rates of air pollution emission from road transportation are show in Table IV.

TABLE IV: AIR POLLUTION EMISSION RATE IN ROAD TRANSPORTATION

\begin{tabular}{|c|c|}
\hline Pollutants & $\begin{array}{c}\text { Rate of Air Pollution Emission (kg. per } \\
\text { ton - } 1000 \mathrm{~km} \text {.) }\end{array}$ \\
\hline $\mathrm{HC}$ & 0.273 \\
\hline $\mathrm{N}_{2} \mathrm{O}$ & 0.273 \\
\hline $\mathrm{CO} 2$ & 0.134 \\
\hline
\end{tabular}

Source: Office of transportation and traffic policy and planning

Amount of carbon dioxide equivalent emission in truck and railway freighting is calculated by using a ton of emission in one year $\left(\mathrm{tCO}_{2} \mathrm{e} /\right.$ year). The calculation of the carbon dioxide emission from truck freighting and railway freighting are according to the following formula.

- Carbon dioxide equivalent emission from truck freighting in one year

$=\{[$ Number of trips which use trucks within a year $*$ distance $(\mathrm{km}) *$ rate of fuel consumption by truck (liter $/ \mathrm{km}) * \mathrm{EF}$ index for carbon dioxide emission $(\mathrm{g} / \mathrm{km}) * \mathrm{GWP}$ of carbon dioxide]

$+[($ Number of trips which use trucks within a year $*$ distance $(\mathrm{km}) *$ rate of fuel consumption by truck (liter / km) * EF index for nitrous oxide $(\mathrm{g} / \mathrm{km})) *$ GWP of nitrous oxide] $+[($ Number of trips which use trucks within a year $*$ distance $(\mathrm{km}) *$ rate of fuel consumption by truck (liter $/ \mathrm{km}) * \mathrm{EF}$ index for methane $(\mathrm{g} / \mathrm{km})) *$ GWP of methane]\}

- Carbon dioxide equivalent emission from railway freighting in one year

$=\{[$ Number of trips which use trains within a year $*$ distance $(\mathrm{km}) *$ rate of fuel consumption by train (liter $/ \mathrm{km}) *$ the weight of 1 liter of fule $(\mathrm{kg}) * \mathrm{EF}$ index for carbon dioxide emission $(\mathrm{g} / \mathrm{km}) * \mathrm{GWP}$ of carbon dioxide]

$+[$ Number of trips which use trains within a year $*$ distance $(\mathrm{km}) *$ rate of fuel consumption by train (liter $/ \mathrm{km}$ ) * the weight of 1 liter of fule $(\mathrm{kg}) * \mathrm{EF}$ index for nitrous oxide emission $(\mathrm{g} / \mathrm{km}) * \mathrm{GWP}$ of nitrous oxide]

$+[$ Number of trips which use trains within a year $*$ distance $(\mathrm{km}) *$ rate of fuel consumption by train (liter $/ \mathrm{km}) *$ the weight of 1 liter of fule $(\mathrm{kg}) * \mathrm{EF}$ index for methane emission $(\mathrm{g} / \mathrm{km}) *$ GWP of methane $]\}$

\section{RESULTS}

OTP has the development plan for shifting freighting mode from trucks to railway. OTP will establish Rail
Transfer Terminal Center in ICD Lat Krabang and delivers all containers to Laem Chabang Port by railway. This project promotes reduction of GHGs emission and adopts the Clean Development Mechanism. First of all, the volume of containers which will be delivered from ICD Lat Krabang to Laem Chabang Port has to be estimated. According to the econometric model which is presented in the previous section, the amount of containers that transport by truck and railway in both scenarios are estimated in Table V.

TABLE V: CONTAINER VOLUMES THAT DELIVER FROM ICD LAT KRABANG TO LEAM CHABANG PORT BY TRUCK AND RAILWAY

\begin{tabular}{|c|c|c|c|c|}
\hline \multirow{2}{*}{ Year } & \multicolumn{2}{|c|}{ Without Project } & \multicolumn{2}{|c|}{ With Project } \\
\hline & Truck & Railway & Truck & Railway \\
\hline 2014 & $1,438,477$ & 505,411 & $1,166,333$ & 777,555 \\
\hline 2015 & $1,485,990$ & 522,105 & $1,204,857$ & 803,238 \\
\hline 2016 & $1,534,918$ & 539,295 & $1,244,528$ & 829,685 \\
\hline 2017 & $1,584,944$ & 556,872 & $1,285,090$ & 856,726 \\
\hline 2018 & $1,635,793$ & 574,738 & $1,326,319$ & 884,213 \\
\hline 2019 & $1,687,240$ & 592,814 & $1,368,033$ & 912,022 \\
\hline 2020 & $1,739,110$ & 611,039 & $1,410,089$ & 940,059 \\
\hline 2021 & $1,791,270$ & 629,365 & $1,452,381$ & 968,254 \\
\hline 2022 & $1,843,625$ & 647,760 & $1,494,831$ & 996,554 \\
\hline 2023 & $1,896,106$ & 666,200 & $1,537,384$ & $1,024,922$ \\
\hline 2024 & $1,948,667$ & 684,667 & $1,580,001$ & $1,053,334$ \\
\hline 2025 & $2,001,277$ & 703,151 & $1,622,657$ & $1,081,771$ \\
\hline 2026 & $2,053,914$ & 721,645 & $1,665,336$ & $1,110,224$ \\
\hline 2027 & $2,106,566$ & 740,145 & $1,708,026$ & $1,138,684$ \\
\hline 2028 & $2,159,224$ & 758,646 & $1,750,722$ & $1,167,148$ \\
\hline 2029 & $2,211,885$ & 777,149 & $1,793,420$ & $1,195,613$ \\
\hline 2030 & $2,264,546$ & 795,651 & $1,836,118$ & $1,224,079$ \\
\hline 2031 & $2,317,205$ & 814,153 & $1,878,815$ & $1,252,543$ \\
\hline 2032 & $2,369,862$ & 832,654 & $1,921,510$ & $1,281,007$ \\
\hline 2033 & $2,422,518$ & 851,155 & $1,964,204$ & $1,309,469$ \\
\hline 2034 & $2,475,173$ & 869,655 & $2,006,897$ & $1,337,931$ \\
\hline 2035 & $2,527,826$ & 888,155 & $2,049,588$ & $1,366,392$ \\
\hline 2036 & $2,580,478$ & 906,654 & $2,092,279$ & $1,394,853$ \\
\hline 2037 & $2,633,129$ & 925,153 & $2,134,969$ & $1,423,313$ \\
\hline 2038 & $2,685,780$ & 943,652 & $2,177,659$ & $1,451,773$ \\
\hline 2039 & $2,738,430$ & 962,151 & $2,220,349$ & $1,480,233$ \\
\hline 2040 & $2,791,080$ & 980,650 & $2,263,038$ & $1,508,692$ \\
\hline 2041 & $2,843,730$ & 999,148 & $2,305,727$ & $1,537,151$ \\
\hline 2042 & $2,914,027$ & $1,000,000$ & $2,348,416$ & $1,565,611$ \\
\hline 2043 & $2,985,175$ & $1,000,000$ & $2,391,105$ & $1,594,070$ \\
\hline
\end{tabular}

The calculation of GHGs reductions in case of successful establishment of the project during the years $2014-2043$ according to the formula in the previous section is shown in Table VI to calculate carbon credits; this study also uses the 
valuation of travel time savings concept [10]. The carbon credits of the project regarding to the Certified Emission Reductions (CERS) that can be traded in the carbon market was valued on April 1, 2010 is 1 ton of carbon dioxide equivalent emission per year equal $€ 11.70$. The exchange rate which is used in this study is from 5 July 2013 was $€ 1$ equals 39.58 baht. The estimation results are shown in Table VI and Table VII.

TABLE VI: COMPARISON OF GHGS RELEASED INTO ATMOSPHERE BETWEEN WITH AND WITHOUT PROJECT FROM YEAR 2014 TO YEAR 2043

\begin{tabular}{|c|c|c|}
\hline Year & $\begin{array}{c}\text { GHGs Emission } \\
\text { without the Project } \\
\left(\mathrm{tCO}_{2} \mathrm{e} / \text { year }\right)\end{array}$ & $\begin{array}{r}\text { GHGs Emission } \\
\text { with the Project } \\
\left(\mathrm{tCO}_{2} \mathrm{e} / \text { year }\right)\end{array}$ \\
\hline 2014 & $734,686.22$ & $660,500.47$ \\
\hline 2015 & $758,952.81$ & $682,316.72$ \\
\hline 2016 & $783,942.10$ & $704,782.68$ \\
\hline 2017 & $809,492.49$ & $727,753.09$ \\
\hline 2018 & $835,463.18$ & $751,101.36$ \\
\hline 2019 & $861,739.22$ & $743,647.34$ \\
\hline 2020 & $888,231.01$ & $766,508.72$ \\
\hline 2021 & $914,871.24$ & $789,498.20$ \\
\hline 2022 & $941,610.88$ & $812,573.47$ \\
\hline 2023 & $968,415.19$ & $835,704.54$ \\
\hline 2024 & $995,260.20$ & $822,978.78$ \\
\hline 2025 & $1,022,129.85$ & $845,197.24$ \\
\hline 2026 & $1,049,013.63$ & $867,427.38$ \\
\hline 2027 & $1,075,904.91$ & $889,663.73$ \\
\hline 2028 & $1,102,799.67$ & $911,902.96$ \\
\hline 2029 & $1,129,695.59$ & $893,403.05$ \\
\hline 2030 & $1,156,591.42$ & $914,673.22$ \\
\hline 2031 & $1,183,486.57$ & $935,942.85$ \\
\hline 2032 & $1,210,380.84$ & $957,211.79$ \\
\hline 2033 & $1,237,274.23$ & $978,480.02$ \\
\hline 2034 & $1,264,166.83$ & $956,038.15$ \\
\hline 2035 & $1,291,058.80$ & $987,973.08$ \\
\hline 2036 & $1,317,950.25$ & $1,019,907.41$ \\
\hline 2037 & $1,344,841.33$ & $1,051,841.29$ \\
\hline 2038 & $1,371,732.12$ & $1,083,774.83$ \\
\hline 2039 & $1,398,622.71$ & $1,115,708.14$ \\
\hline 2040 & $1,425,513.16$ & $1,147,641.28$ \\
\hline 2041 & $1,452,403.52$ & $1,179,574.30$ \\
\hline 2042 & $1,484,104.34$ & $1,211,507.26$ \\
\hline 2043 & $1,516,037.25$ & $1,243,440.17$ \\
\hline
\end{tabular}

Source: authors' calculation

The results showed that the project (Rail Transfer Terminal Center) can reduce GHGs emission year by year whenever the project is established. As the railway freighting has lower GHGs emission rate per unit compared to truck freighting because it can deliver more containers in one trip and consumes less energy. If we compare between the GHGs emission when the project is established and without the project, the reduction of GHGs emissions is at high rate and increases every year.

As you can see, the emission of carbon dioxide equivalent reduces 74,185.75 $\mathrm{tCO}_{2} \mathrm{e}$ per year in year 2014 and reduces up to $272,597.08 \mathrm{tCO}_{2} \mathrm{e}$ per year in year 2043. The value of carbon credit is 33.486 million baht in year 2014 and increases year by year to 123.047 million baht in year 2043 .

TABLE VII: CARBON CREDITS THAT OCCURS WHEN THE PROJECT IS ESTABLISHED FROM YEAR 2014 TO YEAR 2043

\begin{tabular}{|c|c|c|}
\hline Year & $\begin{array}{l}\text { GHGs Reduction } \\
\text { ( } \mathrm{tCO}_{2} \mathrm{e} / \text { year) }\end{array}$ & $\begin{array}{l}\text { Carbon Credit } \\
\text { (Million Baht) }\end{array}$ \\
\hline 2014 & $74,185.75$ & 33.486 \\
\hline 2015 & $76,636.09$ & 34.592 \\
\hline 2016 & $79,159.42$ & 35.731 \\
\hline 2017 & $81,739.40$ & 36.896 \\
\hline 2018 & $84,361.82$ & 38.08 \\
\hline 2019 & $118,091.88$ & 53.305 \\
\hline 2020 & $121,722.29$ & 54.944 \\
\hline 2021 & $125,373.04$ & 56.592 \\
\hline 2022 & $129,037.41$ & 58.246 \\
\hline 2023 & $132,710.65$ & 59.904 \\
\hline 2024 & $172,281.42$ & 77.765 \\
\hline 2025 & $176,932.61$ & 79.865 \\
\hline 2026 & $181,586.25$ & 81.965 \\
\hline 2027 & $186,241.18$ & 84.067 \\
\hline 2028 & $190,896.71$ & 86.168 \\
\hline 2029 & $236,292.54$ & 106.659 \\
\hline 2030 & $241,918.20$ & 109.198 \\
\hline 2031 & $247,543.72$ & 111.738 \\
\hline 2032 & $253,169.05$ & 114.277 \\
\hline 2033 & $258,794.21$ & 116.816 \\
\hline 2034 & $308,128.68$ & 139.085 \\
\hline 2035 & $303,085.72$ & 136.809 \\
\hline 2036 & $298,042.84$ & 134.532 \\
\hline 2037 & $293,000.04$ & 132.256 \\
\hline 2038 & $287,957.29$ & 129.98 \\
\hline 2039 & $282,914.57$ & 127.704 \\
\hline 2040 & $277,871.88$ & 125.427 \\
\hline 2041 & $272,829.22$ & 123.151 \\
\hline 2042 & $272,597.08$ & 123.047 \\
\hline 2043 & $272,597.08$ & 123.047 \\
\hline
\end{tabular}

Source: authors' calculation

The carbon dioxide equivalent emission is approximately 201,256.60 $\mathrm{tCO}_{2} \mathrm{e}$ per year and the total amount of the reduction in 30 years is $6,037,698.04 \mathrm{tCO}_{2} \mathrm{e}$. Additionally, carbon credit that Thailand's government will be gain is averagely 90.84 million baht per year or total values is around 2,725.33 million baht.

From these reason, the project is a powerful policy due to $\mathrm{CO}_{2}$ equivalent emission reduction and generates 
environmental friendly logistics system. Indeed, this project creates greatly sustainable economic values. Moreover, it creates a sustainable transportation system and has a positive impact on society in the long term as well.

\section{CONCLUSION}

The project has a positive impact and support the development of the clean development mechanism. The carbon dioxide equivalent emission is reduced if the Rail Transfer Terminal Center can be successfully established. Thailand's government can gain the carbon credit which created from this project as well.

Therefore, encouragement of investment in transportation and logistics infrastructure, which reduce social and environmental damages in addition to efficiently use of energy, is very important for future improvements. The policy also supports sustainable development in transportation sector.

\section{LIMITATION}

This study does not perform the sensitivity analysis. Thus, the estimation of the container volumes, which will be delivered from ICD Lat Krabang to Laem Chabang Port, is under the normal circumstance. The model assumes there is no economic crisis and other variables remain unchanged.

\section{ACKNOWLEDGMENT}

This research could have been completed only with the kind assistance and dedication of several parties. I wish to express my gratitude towards Office of Transportation and Traffic Policy and Planning, Port Authority of Thailand, and SETEC for the funding and support of other natures; all lecturers of School of Economics and Public Policy, Srinakharinwirot University and Faculty of Graduate School of Management and Innovation, King Mongkut's University of Technology Thonburi for the facilitation. They have extended to the conduct of this research; as well as the workgroup and individuals involved who have all been great contributors.

\section{REFERENCES}

[1] J. T. Houton and L. G. M. Filho, Climate change 1995: The science of climate change, contribution of working group I to the second assessment report of the intergovernmental panel on climate change, 1996.

[2] R. W. Rousseau. (2008). Carbon credits: A non-traditional source of revenue for Mississippi forest landowners. [Online]. Available: http://msucares.com/pubs/publications/p2498.pdf

[3] National Statistical Office, Executive Summary: Energy Consumption of Households 2011, Bangkok, Thailand, 2011.

[4] C. Manchareon, The Reduction of Greenhouse Gases in Transportation Sector in Thailand, Thailand Greenhouse Gas Management Organization, 2000.

[5] Port Authority of Thailand, Annual Report: 2010, Bangkok, Thailand, 2010.

[6] Y. Tappan, Project Evaluation: Economics Approach, Thammasat University, Bangkok, Thailand, 2008.

[7] Office of Transportation and Traffic Policy and Planning, The Project Feasibility Report: 2011, Bangkok, Thailand, 2011

[8] Intergovernmental Panel on Climate Change, Second Assessment Report in Climate Change, USA, 1995

[9] Opus International Consultants. (October 2012). Freight transport efficiency: A comparative study of coastal shipping, rail and road modes. New Zealand Transport Agency research report 497. [Online]. Available: http://www.niwascience.co.nz/ghge/transportation

[10] F. Ahmeda and K. G. Vaidvab, "The valuation of travel time savings in least developed countries: Theoretical and empirical challenges and results from a field study," Arlington, U.K., July 2004.

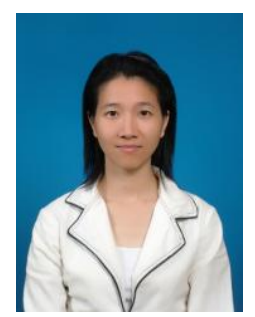

Nantarat Tangvitoontham was born on 11 April, 1977 in Bangkok, Thailand. She graduated her Bachelor Degree in Economics from Thammasat University, Bangkok, Thailand before continuing her study in Washington, D.C., USA. She graduated MA in Economics and MBA from American University, USA. Then she finished her $\mathrm{PhD}$ in Economics from Chulalongkorn University, Bangkok, Thailand in 2009. Now she is a lecturer in School of Economics and Public Policy, Srinakharinwirot University, Bangkok Thailand. Research interests are environmental economics and public policy.

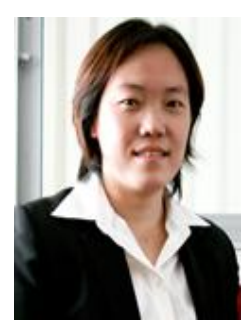

Papusson Chaiwat was born on 6 September, 1977 in Bangkok, Thailand. She graduated her Ph.D in Economics from Chulalongkorn University, Bangkok, Thailand in 2008. Her major field of study are microeconomics, mathematics economics, and econometric. Now she is a lecturer in School of Graduated School of Management and Innovation at King Mongkut's University of Technology Thonburi, Bangmod Tonhkhru, Bangkok Thailand. development economics.
Research interests are mathematical economics and 